\title{
Evaluasi Kritis Penggunaan Membangun Jemaat Dari Perspektif Teologi Kontekstual
}

\author{
Oktoviandy \\ Sekolah Tinggi Agama Kristen Negeri Toraja \\ prantelino@yahoo.co.id
}

\begin{abstract}
Using a qualitative approach we researched and then evaluated the use model of the book Building a Church in the Toraja Church in the South Sangalla Klasis by using a perspective on contextual theology. In this study we found 2 (two) models of using the Church Building book used by the servants there, namely the translation model and the post-translation model. We evaluate these two models as a model of use that is not sufficient to be able to bring the church to the celebration of God's great presence and work that surrounds all. We evaluate Both of these models is still very narrow in providing space for the development of theology and/ or preaching that is truly contextual.
\end{abstract}

Keywords: model, contextual theology, translation, post-translation

\begin{abstract}
Abstrak: Dengan menggunakan pendekatan kualitatif kami meneliti untuk kemudian mengevaluasi model penggunaan buku Membangun Jemaat di Gereja Toraja se-Klasis Sangalla' Selatan dengan menggunakan perspektif teologi kontekstual. Dalam penelitian ini kami menemukan 2 (dua) model penggunaan buku Membangun Jemaat yang digunakan oleh para pelayan di sana, yakni model terjemahan dan model post-terjemahan. Kedua model tersebut kami nilai sebagai model penggunaan yang belum memadai untuk bisa membawa jemaat (gereja) kepada perayaan akan kemahahadiran dan karya Allah yang besar dan yang melingkupi semua. Kedua model itu, kami nilai masih sangat sempit dalam memberi ruang bagi pengembangan teologi dan/atau khotbah yang sungguh-sungguh kontekstual.
\end{abstract}

Kata-kata kunci: model, teologi kontekstual, terjemahan, post-terjemahan

\section{A. Pendahuluan}

Dalam tradisi gereja, khotbah atau berkhotbah merupakan salah satu bentuk atau model berteologi. ${ }^{1}$ Melalui khotbah, seorang pengkhotbah hendak mengomunikasikan kerygma (pesan) yang "diambilnya" dari dalam Alkitab melalui proses hermeneutik atau umumnya disebut eksegetis. Pesan yang dikhotbahkan itu jadi pokok pengajaran kepada jemaat. Namun demikian, dalam khazanah teologi kontekstual, seorang pengkhotbah semestinya tidak hanya memperhatikan teks dan konteks Alkitab, tapi harus juga mengindahkan dengan sungguh-sungguh konteks

1 Steven B. Bevans, Model-model Teologi Kontekstual. Terjemahan Yosef Marian Florisan (Maumere: Ledalero, 2002), 29. Konfrensi Kristen Asia memberi perhatian yang cukup serius terhadap ibadah dan khotbah sebagai salah satu sarana pembaharuan dalam gereja, yang di dalamnya teologi harusnya mampu menghidupkan jemaat. Konprensi Kristen Asia, "Gereja Yang Mengaku di Asia dan Tugas Teologisnya," dalam Teologi Kristen Asia: Tema-tema Yang Tampil ke Permukaan, Peny. Douglas J. Elwood, Terjemahan B.A. Abednego (Jakarta: BPK Gunung Mulia, 2006), 7. 
jemaat di mana teks Alkitab itu dibaca, ditafsirkan, dan dikhotbahkan. Pemahaamn ini sejalan dengan yang diutarakan oleh B.F. Drewes dan Julianus Mojau menegaskan bahwa konteks dalam dunia teologi mencakup segala aspek kehidupan di dalam dan disekitar diri kita. ${ }^{2}$

Malahan, Joséde Mesa dan Lode Wostyn, sebagaimana dirujuk oleh Bevans, memahami bahwa konteks jemaat juga merupakan sumber dari upaya berteologi (baca juga: berkhotbah) itu sendiri, bersama, dan sejajar dengan Alkitab. ${ }^{3}$ Konteks jemaat-dalam hal ini pengalaman jemaat (personal/komunal), kebudayaan yang dihidupinya, perubahan sosial yang sedang dihadapinya, dan lokasi sosial yang ditinggalinya - serta Alkitab yang dibacanya mesti dipandang sebagai dua kutub yang dibaca bersama secara dialektis. Jadi, dengan memperhatikan uraian ini, dapat disimpulkan bahwa pengkhotbah yang baik adalah yang sungguh-sungguh mendialogkan Alkitab dengan konteks jemaatnya yang khas, dan sekaligus menjadikannya sebagai locus theologicus-nya yang sah, saat menyusun khotbah dan berkhotbah.

Berangkat dari itu, menarik bagi kami untuk memusatkan perhatian dan lalu memeriksa secara kritis upaya berteologi Gereja Toraja dalam buku "Membangun Jemaat". Buku "Membangun Jemaat" (selanjutnya ditulis: MJ) merupakan buku yang berisikan kumpulan khotbah dan bahan penelaahan Alkitab yang diterbitkan setahun sekali oleh Gereja Toraja. ${ }^{4}$ Kumpulan khotbah yang menjadi isi buku ini rutin dikhotbahkan di tiap hari Minggu di seluruh Gereja Toraja secara seragam. Khotbahkhotbah tersebut sudah memiliki bahan bacaan, tujuan, dan tema, serta dilengkapi dengan pemahaman teks dan pokok-pokok pikiran-yang telah ditentukan oleh para penulis khotbah-untuk kemudian disampaikan dan dikembangkan oleh setiap pelayan di masing-masing jemaat di mana mereka melayani. Sampai saat ini, buku ini sudah cetakan ke-88 menurut nomor dan tahunnya. Menurut informasi yang kami terima, buku MJ inipun mulai dipakai oleh Gereja Toraja untuk memperlengkapi para pelayannya di tiap-tiap jemaat sejak tahun 1980-an.

Buku MJ ini ditulis oleh kurang lebih 40-an penulis yang ditunjuk oleh Tim Kerja Penyusun Membangun Jemaat. Para penulis yang dimaksud, kebanyakan berlatarbelakang pendidikan teologi dan sekaligus bergelar pendeta. Namun begitu, tidak semua dari mereka adalah pendeta jemaat. Di antara mereka ada yang diberi tugas menjadi pendidik atau dosen teologi di beberapa perguruan tinggi dan sebagiannya lagi adalah pejabat gerejawi di tingkat sinode.

Sudah barang tentu buku MJ ini banyak membantu para pelayan di tingkat jemaat dalam menjalankan tugas pelayanan mereka, khususnya dalam kebaktian di hari Minggu dan kebaktian jemaat lainnya. Para pelayan di masing-masing jemaat tidak repot lagi mencari dan menentukan bahan bacaan, menafsirkan teks Alkitab, menyusun khotbah dan menentukan temanya, karena telah tersedia sedemikian rupa dalam buku MJ. Bahkan kami mendengarkan pengakuan dan menemukan kebiasaan para pelayan yang tidak lagi secara mandiri membaca dan menafsirkan teks Alkitab yang hendak mereka khotbahkan, tapi langsung membaca khotbah dan tafsiran

\footnotetext{
2 B.F. Drewes dan Julianus Mojau, Apa itu Teologi? Pengantar Ke dalam Ilmu Teologi (Jakarta: BPK Gunung MUlia, 2003), 153.

3 Ibid., 28.

${ }^{4}$ Penelitian ini dilaksanakan pada tahun 2017, karena itu yang menjadi acuan pemberitaan jemaat adalah buku Membangun Jemaat untuk tahun tersebut. Tim Membangun Jemaat, Membangun Jemaat No. 88 (Toraja: BPS GT-PT. Sulo, 2017).
} 
sebagaimana yang telah diuraikan oleh penulis khotbah dalam MJ. Khotbah atau tafsiran si penulis di-iya-kan begitu saja.

Selain itu, menurut pembacaan dan pengamatan awal kami, khotbah-khotbah tematik yang menjadi isi buku ini tidak bisa lagi menangkap dan menyoroti isu dan problematika aktual yang khas di masing-masing jemaat. Para pelayan (tidak semua, tapi pada umumnya) dibuat menjadi kurang peka, tidak mandiri, dan pasif dalam berteologi secara otentik dan kreatif di tengah konteks jemaat yang mereka layani. Seringkali, bacaan Alkitab dan tema khotbah yang telah ditentukan, justru mengkondisikan pengkhotbah atau para pelayan sedemikian rupa, yang pada akhirnya justru memaksa mereka bukan berteologi secara dialektis dan kontekstual, tapi malah ber-cocok-logi dan melulu konversionis.

Karena itu, berdasarkan beberapa uraian di atas, kami termotivasi untuk mengevaluasi model penggunaan buku MJ ini di Gereja Toraja Klasis Sanggala' Selatan dalam perspektif teologi kontekstual. Evaluasi yang dimaksud didasarkan pada kesaksian dan pengalaman para pelayanan di 9 (sembilan) jemaat yang ada di Klasis Sanggala' Selatan. Kesaksian dan pengalaman mereka saat berkhotbah dengan berpedoman pada bahan bacaan, tujuan, tafsiran, dan tema yang disiap-sajikan oleh buku MJ. Kemudian kami akan mengevaluasi lagi model-model penggunaan buku MJ itu oleh para pelayan di jemaatnya masing-masing menurut perspektif teologi kontekstual. Untuk itu penelitian ini diberi judul: "Model Penggunaan Buku Membangun Jemaat: Evaluasi Kritis Menurut Perspektif Teologi Kontekstual.

Bertolak dari latar belakang masalah di atas maka rumusan masalah dari penelitian ini dirumuskan dalam pertanyaan penelitian sebagai berikut: bagaimana evaluasi kritis terhadap model penggunaan buku Membangun Jemaat di Gereja Toraja Klasis Sanggala' Selatan dalam perspektif teologi kontekstual? Berdasarkan perumusan masalah di atas, maka tujuan dari penelitian ini adalah: menguraikan evaluasi kritis terhadap model penggunaan buku Membangun Jemaat di Gereja Toraja Klasis Sanggala' Selatan dalam perspektif teologi kontekstual.

Untuk mendapatkan data yang dibutuhkan, peneliti menggunakan metode library research atau studi kepustakaan yaitu usaha untuk memperoleh data dengan cara mendalami, mencermati, menelaah dan mengidentifikasi pengetahuan yang ada dalam kepustakaan, baik itu sumber bacaan, buku referensi atau hasil penelitian lain. ${ }^{5}$ Selain itu, penulis juga menggunakan metode observasi, yakni melakukan observasi (peninjauan langsung) ke jemaat-jemaat se-klasis Sangalla' Selatan di saat kebaktian Minggu untuk mengetahui secara langsung bagaimana para pelayan di Klasis Sanggala' Selatan menggunakan MJ dalam khotbah-khotbah mereka; serta melakukan wawancara tidak terstruktur dengan para pendeta dan proponen yang ada di Klasis yang dimaksud.

\section{B. Pengkhotbah, Khotbahnya, dan Konteksnya}

Sudah diuraikan sebelumnya bahwa buku MJ merupakan buku yang berisi khotbah yang relatiframpung, telah dilengkapi dengan bahan bacaan, tujuan, tema, tafsiran, dan pokok-pokok pikiran yang ditulis oleh penulis-penulis yang telah ditunjuk oleh satu Tim Kerja. Khotbah-khotbah yang disusun itu, sudah barang tentu-disadari atau tidak-dipengaruhi oleh subjektifitas pribadi, wawasan, dan konteks para penulisnya. Karena itu, bisa dipastikan bahwa khotbah yang disusun di dalam buku MJ itu kontekstual dalam takaran subjektifitas para penulisnya.

\footnotetext{
${ }^{5}$ Lexy J. Moleong, Metodologi Penelitian Kualitatif (Bandung: PT Rosdakarya, 2002), 3-4.
} 
Perihal di atas sungguh menjadi persoalan dalam perspektif teologi kontekstual, saat khotbah para penulis MJ itu dikomunikasi oleh subjek atau pengkhotbah lain yang konteks gumul jemaatnya sungguh khas dan unik. Di titik ini, para penulis MJ, tentunya harus dipandang sebagai orang yang non-partisan dalam konteks jemaat-jemaat lokal, di mana nantinya khotbah mereka itu "wajib" direfkesikan. Para pelayan di aras lokal kemudian secara tidak langsung "dipaksa" menggumuli teks Alkitab, tema, tujuan, dan pokok-pokok pikiran khotbah yang tidak benar-benar sesuai dengan pergumulan konteksnya. Pengkhotbah di situasi ini menjadi asing dengan khotbahnya, dan bahkan diasingkan dari konteksnya.

Dalam problematika demikian, para teolog kontekstual pasti akan mengajukan pertanyaan kritisnya, bahwa dapatkah seseorang yang tidak turut serta dalam sebuah pengalaman kebudayaan dan lokasi sosial tertentu sungguh-sungguh berteologi secara otentik di dalam kebudayaan atau konteks tertentu itu? ${ }^{6}$ Secara konkret, dalam konteks penelitian ini, pertanyaan di atas bisa diajukan demikian: dapatkah seorang penulis khotbah yang tidak hidup dan/atau berasal dari konteks jemaatjemaat yang ada di Klasis Sanggala' Selatan mampu menulis khotbah dan teologi yang kontekstual di sana? Dari satu sudut pandang, menyetir Emerson, Bevans menyatakan bahwa untuk menjawab pertanyaan ini, kita mesti dengan tegas menyatakan "tidak", karena seorang pribadi yang tidak sepenuhnya turut serta dalam pengalaman kita tidak boleh seluruhnya dipercaya untuk berbicara tentang Allah seturut konteks orang tersebut. ${ }^{7}$

Jadi, bisa dipahami bahwa seorang pengkhotbah harus benar-benar memahami khotbahnya, menentukan bahan bacaan, tujuan, tema, dan pokok-pokok pikirannya sendiri seturut dengan konteksnya. Khotbah para penulis di buku MJ bisa dipakai sebagai pembanding dan mungkin juga ditempatkan sebagai konteks yang perlu dipertimbangkan sejauh dianggap relevan.

\section{Teologi Kontekstual Dalam Khotbah dan Berkhotbah}

Ungkapan yang paling sering dinyatakan saat orang bicara tentang teologi kontekstual ialah, bahwa tidak ada sesuatu yang disebut "teologi"; yang ada hanya teologi kontekstual. Pernyataan ini, seharusnya dipahami juga bahwa tidak ada teologi yang senantiasa kontekstual. Tidak ada teologi tunggal yang serta merta tepat untuk semua konteks. ${ }^{8}$ Di sini, jelas, bahwa dalam teologi kontekstual, segala upaya "penyeragaman teologi" tidak dapat diterima.

Jadi, sudah dapat disinyalir, bahwa buku MJ merupakan salah satu bentuk penyeragaman konteks dan bahkan teologi di tengah kekhasan dan kemajemukan konteks jemaat di Gereja Toraja. Tanpa ragu pula, teologi kontekstual dimengerti sebagai sesuatu yang sangat subjektif. ${ }^{9}$ Maksudnya, semua pribadi dan masyarakat manusia, betapapun itu, pasti terikat secara kultural dan historis.

Dalam pemahaman teologi kontekstual, bisa dikatakan bahwa pengkhotbah dan khotbahnya harus benar-benar menyadari bahwa Alkitab dan isinya bukanlah sesuatu yang diturunkan langsung dari langit. Semuanya itu merupakan hal-hal yang dihasilkan oleh manusia dan konteks kehidupan mereka. Karena itu, saat kita mempelajari Alkitab dan tradisi Gereja, kita tidak saja harus menyadari ciri

\footnotetext{
${ }^{6}$ Bevans, Model-model Teologi Kontekstual, 32.

${ }^{7}$ Ibid., 33.

8 Ibid., 1.

${ }^{9}$ Bernard Lonergan, Method in Theology (Darton: Longman and Todd, 1972), 263.
} 
kontekstualnya yang tak terelakkan; kita juga harus membaca dan menafsirkan keduanya dalam konteks kita sendiri.

Karena itu, dalam hal ini dapat dikatakan bahwa berteologi (baca juga: menyusun khotbah dan berkhotbah) secara kontekstual berarti berteologi yang serentak menghiraukan dua hal sekaligus. Pertama, dihiraukannya pengalaman iman dari masa lampau yang terekam dalam Alkitab, dan dijaga agar tetap hidup, dilestarikan serta dibela-barangkali juga diabaikan atau ditindas dalam tradisi; dan kedua, bahwa berteologi secara kontekstual juga harus secara sungguh-sungguh mengindahkan pengalaman masa sekarang, atau konteks aktual. Jadi, ini berarti bahwa seorang pengkhotbah dan khotbahnya dalam perspektif kontekstualitas, harus juga memperhatikan perihal tersebut secara sungguh-sungguh.

\section{Model-Model Penggunaan Buku MJ Di Gereja Toraja Se-Klasis Sangalla' Selatan}

1. Model Terjemahan

Model terjemahan yang dimaksudkan di sini memiliki kerangka berpikir yang sama dengan model teologi kontekstual Bevans yang pertama dalam bukunya "Model-model Teologi Kontekstual."10 Namun begitu, di sini, model terjemahan yang kami maksudkan bukan hanya sebuah upaya "menerjemahkan" isi kitab suci ke dalam konteks, tapi tentang bagaimana "isi MJ" diterjemahkan, diakomodasikan, dan atau diadaptasikan ke dalam konteks jemaat. Tujuh dari sembilan pelayan yang menjadi responden kami dalam penelitian ini secara persis memahami dan memberlakukan MJ dalam kerangka model terjemahan yang kami maksudkan tersebut.

Tema, pemahaman teks Alkitab, dan pokok-pokok pikiran yang ditawarkan oleh penulis MJ diandaikan sebagai sesuatu yang "suprakonteks". Dalam wawancara kami, tujuh responden memberi komentar yang relatif sama tentang tiga hal di atas. Tema, pemahaman teks, dan pokok-pokok pikiran dalam khotbah-khotbah yang ada dalam MJ dianggap sangat membantu (diubah seperlunya) dan dipertimbangkan untuk kemudian disesuaikan dengan konteks jemaat.

Dalam wawancara tersebut kami-pun menemukan bahwa mereka mengontekstualisasi "isi MJ" hanya pada level penyesuaian bahasa (bahasa Indonesia diterjemahkan ke dalam bahasa Toraja atau dari bahasa yang teknis akademis diterjemahkan ke dalam bahasa sehari-hari yang menurutnya lebih operasional). Robert J. Shreiter menyebu model ini dengan istilah penerjemahan ekuivalendinamis. ${ }^{11}$ Di sisi yang lain, konteks jemaat tidak dimengerti sebagai "rahim" yang telah mengandung "benih sabda", tapi hanya sebagai "rahim" yang lemah dan selalu butuh untuk disabdai.

Perlu juga dicatat di sini bahwa semua responden (sembilan responden) memiliki catatan kritis-sebagai temuan mereka-bahwa uraian pemahaman teks Alkitab yang diuraikan di dalam buku MJ oleh para penulis, kadang tidak memiliki relevansi antara satu dengan yang lainnya dan bahkan irelevan dengan tema khotbah yang ditawarkan. Sehingga, menurut penuturan mereka, kadang mereka harus membaca kembali dan/atau dengan mandiri menafsirkan kembali teks-teks tersebut secara eksegetis.

\footnotetext{
10 Bevans, Model-model Teologi Kontekstual, 63-87.

11 Robert J. Schreiter, Rancang Bangun Teologi Lokal, Terjemahan Stephen Suleeman (Jakarta: BPK Gunung Mulia, 1996), 15.
} 


\section{Model Post-terjemahan}

Sedikit berbeda dan relatif sedikit melampaui model sebelumnya yang menjadikan buku MJ sebagai acuan utama dan bahkan menganggapnya "suprakonteks". Para praktisi model post-terjemahan ini hanya menempatkan "isi MJ" sebagai salah satu alat bantu saja. Artinya, jika "isi MJ" dianggap sesuai dengan konteks jemaat maka akan dipertimbangkan, jika tidak, maka diabaikan saja. Tema, pemahaman teks, dan pokok-pokok pikiran, bisa diabaikan saat tidak relevan, tapi bacaan Alkitab yang ditetapkan sebagai bahan utama dalam MJ, dibaca, ditafsirkan sendiri, dan mereka kemudian membuat pokok-pokok khotbahnya secara mandiri.

Namun demikian, menurut temuan kami, dua responden yang kami posisikan sebagai praktisi model post-terjemahan ini, masih menafsirkan teks-teks Alkitab secara eksegetik-adaptatif-akomodatif, dibanding memilih membaca Alkitab dalam kesadaran hermeneutik kontekstual. Persis dengan model sebelumnya, "isi MJ (yang dianggap relevan)" atau "isi Alkitab" yang ditafsirkan hanya dikontekstualisasi dalam pengertian adaptatif-akomodatif terhadap bahasa lokal dan/atau dengan pola penyederhanaan bahasa dalam mengomunikasikan "isi MJ" atau "isi Alkitab" dalam berkhotbah. Konteks jemaat-pun masih dimengerti sebagai "rahim" yang tidak mengandung "benih sabda".

\section{Evaluasi Kritis Terhadap Mode Penggunaan Buku MJ}

\subsection{Model-model Penggunaan MJ Menurut Perspektif Teologi Kontekstual}

Sudah kami uraikan di bab sebelumnya bahwa ada dua model penggunaan buku MJ yang diterapkan di gereja-gereja Toraja se-Klasis Sangalla' Selatan, yakni: model terjemahan dan model post-terjemahan. Kedua model ini memiliki perbedaan dan kesamaan, yang juga telah kami uraikan sebelumnya.

Para praktisi model terjemahan (tujuh responden) menunjukkan kesetiaannya kepada "isi MJ", dengan menjadikan MJ sebagai acuan utamanya (tema, pemahaman teks, dan pokok-pokok pikiran dianggap "suprakonteks"), sedangkan para praktisi model post-terjemahan (dua responden) memahami buku MJ hanya sebagai salah satu alat bantu. "Isi MJ" hanya dipakai sejauh relevan dalam dan dengan konteks jemaat.

Namun demikian, praktisi model terjemahan dan praktisi model postterjemahan pun memiliki kesamaan yang mencolok dalam memahami dan mempraktikkan proses kontekstualisasi dalam berkhotbah. Kedua praktisi model yang dimaksud memahami konteks jemaat hanya sebagai "rahim" yang senantiasa perlu disabdai dan bukan sebagai "rahim" yang sedang mengandung "benih sabda".

Dalam kesadaran yang demikian itu, para praktisi model-model tersebut sebenarnya baru sampai pada tahap kontekstualisasi teologi dan belum tiba pada fase yang utuh dari apa yang disebut berteologi, menyusun khotbah, dan/atau berkhotbah secara kontekstual.

Mereka masih memahami dan memperlakukan konteks jemaat (pengalaman individu dan komunalnya, kebudayaannya, lokasi sosial, dan perubahan sosialnya) layaknya "mangkok kosong" yang selalu harus diisi "bakso". Walaupun, misalnya, "mangkok" itu telah berisi, tapi isinya bukan "bakso", maka segera harus diganti dengan "bakso". Apapun "mangkok"nya, isinya mestilah "bakso".

Kelemahan mendasar dari praktik berteologi seperti ini ialah paradigma positivisme dihidupkan secara sadar ataupun tidak oleh para pelayan se-Klasis Sangalla' Selatan. Yang melihat konteks jemaatnya sebagai sesuatu yang bebas nilai. "Isi MJ" dan "isi Alkitab" yang mereka baca belum disadari sebagai sesuatu hal yang 
juga dikondisikan secara kultural dan selalu merupakan respons dari manusia yang hidup di zaman tertentu dengan situasi sosio-historis yang khas pula. Belum disadari dengan sungguh oleh para pelayan di sana, bahwa teks-teks Alkitab bukan merupakan hasil proses dikte dari surga, melainkan "Injil" yang tidak dapat dilepaspisahkan dari rumusan manusia dalam konteks sosio-historis dan kultural tertentu.

Masih dalam kaitannya dengan paradigma positivisme yang menurut kami masih diwarisi oleh para pelayan di Klasis Sangalla' Selatan. Belum dipahami oleh mereka, bahwa penting juga untuk mengindahkan konteks jemaat sebagai sumber teologi dan tempat di mana Allah telah dan sedang bersabda. Sebab dalam pengalaman hidup jemaat-pun Allah menyatakan diri-Nya secara khas dalam pengalaman individu maupun komunal jemaat yang khas pula. Sebagaimana kutipan Bevans tentang ungkapan M. A. C. Warren, demikian: "kerendahan hati yang mendalam olehnya kita mengingat bahwa Allah tidak membiarkan diri-Nya sendirian tanpa seorang saksi pun di setiap bangsa dan pada segala waktu...ketika kita mendekati orang yang beriman, maka hendaknya itu dilakukan...(yakni) untuk menemukan bagaimana Allah telah dan terus berbicara kepadanya...tugas kita yang pertama dalam mendekati orang lain, kebudayaan lain...ialah menanggalkan kasut kita, karena tempat yang hendak kita dekati itu adalah kudus. Kalau tidak, bisa saja kita malahan menginjak-injak impian manusia. Atau lebih celaka lagi, kita barangkali lupa bahwa Allah sudah ada di sana sebelum kita sampai."12

Perihal di atas dapat diungkapkan secara analogis-teologis demikian: bahwa Allah tidak hanya berkenan mendatangi warung bakso, menyapa tukang bakso, menikmati bakso itu dengan mangkoknya yang khas, dan lalu memberi berkat dan komentar-Nya yang khas pula kepada si tukang bakso, tapi Allah-pun berkenan untuk memasuki warung coto, menyapa tukang coto, menikmati coto itu dengan takaran mangkoknya yang juga khas, dan kemudian memberi berkat dan komentar-Nya yang khas pula kepada si tukang coto. Artinya, jika hal ini dihubungkan dengan pokok persoalan dari model penggunaan buku MJ oleh para pelayan di Klasis Sanggalla' Selatan, mereka seharusnya tidak hanya "mendengar" kesaksian atau respons si tukang bakso tentang berkat Allah kepadanya dan apa komentar Allah tentang diri dan pelayanannya, warungnya, baksonya, dan besaran mangkoknya, tapi perihal yang sama-pun harus pula "didengarkan" dari si tukang coto dalam seluruh kekhasannya.

\subsection{Berteologi Kontekstual: Ada atau Tidak Adanya Buku MJ}

Sudah diuraikan di bab-bab sebelumnya bahwa dalam teologi kontekstual tidak hanya mengakui kitab suci dan tradisi gereja sebagai locus theologicus yang sah, tapi juga terbuka dan mengakui keabsahan sumber-sumber berteologi lainnya, yakni pengalaman manusia sekarang ini. Sebab dipahaminya bahwa teologi yang berwajah kontekstual menyadari bahwa kebudayaan, sejarah, bentuk-bentuk pemikiran kontemporer, dll., harus diindahkan, bersama kitab suci dan tradisi, sebagai sumbersumber yang sah untuk ungkapan teologis. ${ }^{13} \mathrm{Hal}$ ini bermakna bahwa, konteks jemaat sudah sangat kaya dengan sumber-sumber teologi yang dimaksud. Jadi, ada atau tidaknya buku MJ, para pelayan sudah memiliki sumber dan referensi yang melimpah di jemaatnya masing-masing. Semua sisa tergantung pada kesediaan dan kepekaan masing-masing pelayan.

Memang dapat dipahami, bahwa model berteologi terjemahan dan yang kami sebut sebagai model post-terjemahan itu, selain sebagai model yang klasik (paling

12 Bevans, Model-model Teologi Kontekstual, 99.

13 Ibid, 2. 
tua), juga masih merupakan model umum yang dipakai dalam gereja, termasuk di dalam gaya berteologi para pelayan di Gereja Toraja. Sebab, model ini dianggap paling setia kepada Kitab Suci dan tradisi. Namun, dalam pengembangan teologi gereja yang kontekstual, model ini tidak lagi memadai untuk bisa membawa jemaat (gereja) kepada perayaan akan kemahahadiran dan karya Allah yang besar dan yang melingkupi semua. Itulah sebabnya, di sini, kami coba menawarkan model penggunaan MJ (jika ingin diteruskan penggunaanya) yang menurut kami lebih pas, agar penggunaan MJ tersebut tetap dapat memberi ruang yang lebih luas bagi berkembangnya teologi kontekstual (baca juga: khotbah kontekstual) di jemaat.

Di sini kami mengikuti kerangka kerja model sintesis (dialektis), sebagai model keempat dari model teologi kontekstual yang diuraikan oleh Bevans dalam bukunya. Model ini kami anggap dapat "mendengar" semua ungkapan teologis dari seluruh sumber teologi lainnya, di samping kitab suci, tradisi gereja, dan termasuk yang terekam dalam buku MJ. Kerangka kerja dari model ini dibahasakan kembali dalam bentuk gambar yang didalamnya model penggunaan MJ turut diandaikan sebagai proses berteologi, mempersiapkan khotbah, dan/atau berkhotbah secara kontekstual.

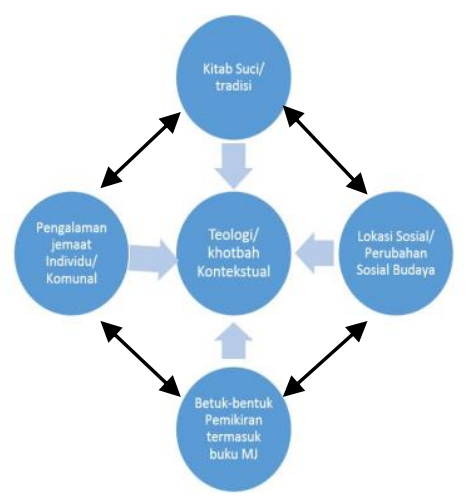

Secara ringkas gambar di atas menjelaskan bahwa setiap pelayan semestinya mendengar, membaca, mengasah kepekaannya, dan senantiasa bersedia untuk berdialog secara jujur dan terbuka dengan semua ungkapan sosio-teologis yang mungkin hadir dari setiap sumber (locus theologicus) yang ada di jemaatnya untuk kemudian mampu mempersiapkan khotbah dan berkhotbah secara teologi kontekstual. Buku MJ-pun dianggap sebagai salah satu dari sekian banyak sumbersumber teologi lainnya. Jika hal ini diterapkan secara maksimal, maka setiap jemaat atau klasis bisa menyusun buku MJ sendiri menurut konteks gumulnya masingmasing. Dan setiap pelayan di masing-masing jemaat ataupun klasis kemudian, secara mandiri, diberi tanggungjawab dan sekaligus berdaya untuk terus menerus berteologi secara kontekstual. Inilah yang dimaksud oleh Shokie Coe sang pencentus istilah teologi kontekstual di Asia, bahwa kontekstualisasi adalah sebuah pemaknaan kritis supaya konteks benar-benar bermakna di dalam terang Missio Dei. ${ }^{14}$

${ }^{14}$ Shokie Coe, "Kontekstualisasi Sebagai Jalan Menuju Pembaruan," dalam Teologi Kristen Asia: Tema-tema Yang Tampil ke Permukaan, Peny. Douglas J. Elwood, Terjemahan B.A. Abednego (Jakarta: BPK Gunung Mulia, 2006), 16. 


\section{E. Penutup}

Berdasarkan uraian yang telah kami lakukan pada bab-bab sebelumnya, pada bab penutup ini kami menarik kesimpulan dan saran yang terkait dengannya. Ditemukan dalam penelitian ini, bahwa ada dua model penggunaan buku MJ yang diterapkan oleh para pelayan di Gereja Toraja se-Klasis Sangalla' Selatan. Kedua model itu, kami namakan model terjemahan dan model post-terjemahan. Kedua model tersebut kami nilai sebagai model penggunaan yang belum memadai untuk bisa membawa jemaat (gereja) kepada perayaan akan kemahahadiran dan karya Allah yang besar dan yang melingkupi. Kedua model itu, kami nilai masih sangat sempit dalam member ruang bagi pengembangan teologi dan/atau khotbah yang sungguh-sungguh kontekstual.

Berdasarkan kesimpulan di atas, serta memperhatikan data-data yang diperoleh, kami tiba pada beberapa rekomendasi pemikiran sebagai saran untuk dikaji dan dilaksanakan: Pertama: para pelayan di Gereja Toraja se-Klasis Sanggala' Selatan sudah selayaknya mempertimbangkan kembali model penggunaan buku MJ di jemaatnya masing-masing dengan memperhatikan konteks jemaat secara lebih serius dan bersungguh-sungguh sebagaimana yang sudah kami uraikan dalam penelitian ini. Kedua: pihak yang kedua yang kami beri rekomendasi sehubungan dengan hasil penelitian ini adalah BPWG Gereja Toraja. Sekiranya di waktu-waktu mendatang, buku MJ ini dapat ditulis dan diproduksi di masing-masing jemaat ataupun klasis yang ada di Gereja Toraja. Untuk kemudian memastikan bahwa khotbah-khotbah yang ada di jemaat dan klasis sungguh-sungguh digumuli dan ditulis berdasarkan konteks riil yang ada di masing-masing jemaat ataupun klasis.

\section{Daftar Pustaka}

Bevans, Stephen, B., Model-model Teologi Kontekstual. Maumere: Ledalero, 2002.

Coe, Shokie. "Kontekstualisasi Sebagai Jalan Menuju Pembaruan," dalam Teologi Kristen Asia: Tema-tema Yang Tampil ke Permukaan, Peny. Douglas J. Elwood, Terjemahan B.A. Abednego, 10-18, Jakarta: BPK Gunung Mulia, 2006.

Drewes, B. F. dan Julianus Mojau. Apa itu Teologi: Pengantar ke dalam Ilmu Teologi, Jakarta: BPK Gunung Mulia. 2007.

Konperensi Kristen Asia. "Gereja Yang Mengaku Di Asia dan Tugas Teologisnya" dalam Teologi Kristen Asia: Tema-tema Yang Tampil ke Permukaan, Peny. Douglas J. Elwood, Terjemahan B.A. Abednego, 3-9, Jakarta: BPK Gunung Mulia, 2006.

Lonergan, Bernard. Method in Theology. Darton: Longman and Todd, 1972.

Moleong, Lexy J. Metodologi Penelitian Kualitatif. Bandung: PT Rosdakarya, 2002.

Schreiter, Robert J. Rancang Bangun Teologi Lokal. Terjemahan Stephen Suleeman, Jakarta: BPK Gunung Mulia, 1996.

Tim Membangun Jemaat, Membangun Jemaat No. 88, Toraja: BPS Gereja Toraja-PT. Sulo, 2017. 